\title{
Fasade Bangunan Gedung SMPN 16 Kota Cirebon
}

\author{
Fahrul Rozi ${ }^{1}$, Iwan Purnama ${ }^{1}$ \\ ${ }^{1}$ Program Studi Arsitektur - Sekolah Tinggi Teknologi Cirebon \\ Email: zhiee95@gmail.com
}

\begin{abstract}
ABSTRAK
Kota Cirebon memiliki kawasan yang erat kaitannya dengan bangunan kolonial. Kawasan ini dikenal sebagai kawasan Kolonial yang termasuk kawasan cagar budaya. Kawasan Kolonial berlokasi di Kecamatan Lemah Wungkuk yang merupakan kota lama Cirebon. Hingga saat ini masih terdapat banyak bangunan peninggalan pemerintah kolonial Belanda, salah satunya adalah Gedung SMP Negeri 16 Kota Cirebon, Bangunan ini diperkirakan dibangun pada tahun 1933 dan berfungsi sebagai asrama tentara Belanda. Gedung ini tidak berdiri sendiri, terdapat bangunan lain disekitarnya seperti SMP Negeri 14, Gedung PT Tjipta Niaga, Gereja Kristen Pasundan dan beberapa lainnya yang menghadap ke Taman Kebumen sebagai porosnya. Berbeda dengan bangunan kolonial pada umumnya, bangunan SMP Negeri 16 Kota Cirebon tidak terlalu besar tetapi memiliki fasad yang terbilang unik. Oleh karenanya dinilai menarik untuk mempelajari elemen pembentuk karakteristik fasadnya. Metode penelitian deskriptif dilakukan dengan survei ke lapangan, sebagai proses pengumpulan data-data yang dibutuhkan. Hasil analisis disajikan dengan menguraikan masing-masing elemen pembentuk fasad mulai dari atap hingga lantai bangunan. Diharapkan hasil dari penelitian ini menambah pengetahuan dan wawasan keilmuan tentang elemen fasad bangunan kolonial di kota Cirebon. Selanjutnya dengan mempelajari karakter bangunan kolonial sebagai bangunan cagar budaya akan menimbulkan kecintaan terhadap warisan budaya sehingga upaya pelestarian bangunan cagar budaya dapat ditingkatkan.
\end{abstract}

Kata kunci: arsitektur Kolonial, fasad bangunan, kawasan cagar budaya, kota Cirebon

\begin{abstract}
Cirebon city has an area closely linked to the colonial buildings. This area is known as the Colonial area which includes the area of cultural heritage. The colonial area is located in sub-district Lemah Wungkukt which is the old city of Cirebon city. Until now, there are still many buildings from the Dutch colonial government, one of which is the SMP Negeri 16 Cirebon City Building. The building was probably built in 1933 and was originally a dormitory of the Dutch army. This building does not stand alone, there are other buildings around it such as SMP Negeri 14, PT Tjipta Niaga Building, Pasundan Christian Church and several others that face Kebumen Park as its axis.Unlike colonial buildings in general, the SMP Negeri 16 Cirebon City building is not too big but has a unique facade. Therefore, it is considered interesting to study the elements forming the characteristics of its facade. The descriptive research method was carried out by surveying the field, as a process of analyzing the required data. The research analysis result are presented by describing each of the elements that form the facade from the roof to the building floor. Expected research outputs to increase knowledge and insight on the facade elements of colonial buildings in the city of Cirebon. It is also hoped that by studying the character of colonial buildings as cultural heritage buildings, it will lead to love for cultural heritage so that efforts to conserve cultural heritage buildings can be increased.
\end{abstract}

Keywords: building facade, cirebon city, colonial architecture, conservation area, 


\section{PENDAHULUAN}

Cirebon adalah salah satu kota yang berada disebelah ujung paling timur provinsi Jawa Barat. Kota ini mempunyai sejarah pada jaman penjajahan kolonial dan memliki beberapa peninggalan. Salah Satu Kecamatan di Kota Cirebon yaitu Kecamatan Lemah Wungkuk Kelurahan Lemah Wungkuk atau tepatnya berlokasi di jalan Kebumen merupakan daerah yang memiliki keterikatan erat dengan sejarah kolonial. Di daerah tersebut terdapat bangunan bersejarah peninggalan kolonial yang menarik, salah satunya adalah bangunan Sekolah Menengah Pertama Negeri 16 Kota Cirebon (SMPN 16 Kota Cirebon).

Bangunan saat ini berfungsi sebagai sekolah SMPN 16 Kota Cirebon diperkirakan dibangun sekitar tahun 1933 dan merupakan bangunan cagar budaya yang sudah dilindungi oleh Pemerintah daerah Cirebon berdasarkan surat keputusan Walikota Cirebon no 9 tahun 2001 dan terdaftar pada Situs/Benda Cagar Budaya Kota Cirebon [1]. Bangunan ini terlihat kokoh, menarik oleh karenanya dipilih sebagai studi kasus. Pada awal pendiriannya bangunan ini tidak difungsikan untuk sekolah melainkan sebagai asrama tentara kolonial Belanda. Perbedaan sejarah fungsi awal ini terutama terlihat dari tampilan fasad bangunannya yang berbeda dengan fasad bangunan sekolah ex Kolonial yang dibangun pada era yang sama, seperti halnya SMAN 3 yang berlokasi di eks kawasan Kolonial di jl Belitung kota Bandung.

Makalah ini akan memaparkan bentuk, gaya bangunan dan elemen-elemen pembentuk fasad pada bangunan SMPN 16 Kota Cirebon. Apakah peralihan fungsi dari asrama menjadi sekolah memberikan pengaruh terhadap fasad bangunan SMPN 16 Kota Cirebon sebagai bangunan cagar budaya,

\section{METODOLOGI}

Penelitian kualitatif deskriptif digunakan pada penelitian ini. Tujuan dari metode deskriptif untuk mengetahui beberapa hal berkaitan dengan kondisi objek studi. Metode ini dilaksanakan melalui pengumpulan data lapangan hasil survey secara langsung dalam bentuk dokumentasi objek atau sketsa, dan kajian pustaka yang berkaitan dengan objek penelitian [2]. Cara pengambilan dokumentasi atau pembuatan sketsa melalui pemotretan kondisi bangunan serta pencatatan informasi maupun data yang didapatkan dari lapangan.

Langkah awal penelitian ini adalah melakukan studi literatur dengan melakukan kajian berbagai sumber konsep, tulisan, serta teori terkait perkembangan langgam/ gaya arsitektur kolonial yang terdapat di Indonesia serta kaji literatur mengenai elemen bangunan pembentuk fasad. Data-data yang diperoleh dipergunakan dalam proses analisis fasad bangunan SMPN 16 Kota Cirebon.

Langkah selanjutnya adalah melaksanakan survey langsung ke objek bangunan yang menjadi amatan. Tujuan dari pelaksanaan survey ini adalah pengumpulan data yang diperlukan pada proses penggambaran fasad bangunan. Hasil survey kemudian dipaparkan dalam bentuk gambar denah, dan tampak bangunan, serta material bangunan yang diterapkan fasad bangunan. Selain itu dapat diidentifikasi elemen pembentuk fasad, seperti dinding eksterior, pintu dan jendela, bentuk atap, lantai, penggunaan warna pada bangunan serta gaya bangunan. Dari hasil analisis dapat disimpulkan bentuk fasad dan gaya arsitektur yang diterapkan pada bangunan SMPN 16 Kota Cirebon.

\subsection{Kerangka Teori}

Menurut Safeyah (2006), arsitektur kolonial merupakan gaya arsitektur kolaborasi dari budaya Timur dan Barat. Pada masa pemerintah Kolonial Belanda, langgam Arsitektur Kolonial merupakan hasil karya dari seorang arsitek berkebangsaan Belanda yang diperuntukan bagi masyarakat yang berasal dari Belanda yang tinggal di Indonesia [3]. Sejalan dengan itu, Akihari (1990) dan Handinoto \& Soehargo (1996) menjelaskankan adanya pembagian dua periode pada Arsitektur kolonial Belanda, yaitu Arsitektur kolonial yang termasuk pada masa sebelum abad XVIII dan Arsitektur kolonial yang termasuk pada masa setelah abad XVIII [4]. 
Menurut Handinoto (2010), pembagian Tiga Periode Arsitektur Kolonial, yaitu [5]:

a. Langgam Indische Empire (1870-1900), pada abad ke-19 mulai berkembang langgam Arsitektur di wilayah Hindia-Belanda yang dikenal dengan langgam Indische Empire. Jenderal HW Daendles (1808-1811) membuat langgam ini lebih dikenal oleh masyarakat yang lebih luas. Langgam ini memiliki karakter bangunan dengan ciri khas penggunaan atap perisai, bangunan tidak bertingkat, memiliki denah simetris, image bangunan monumental. Bangunan dengan langgam ini memiliki ruang terbuka yang luas, dan terdiri dari beberapa masa bangunan yaitu bangunan induk atau bangunan pokok serta bangunan pendukung atau bangunan penunjang yang saling terhubung dengan masa bangunan lainnya. Penghubung massa bangunan menggunakan serambi atau penggunaan gerbang. Penghubung antar serambi menggunakan koridor. Penggunaan pilar atau kolom-kolom bergaya yunani (Doric, Ionic, dan Corintian pada serambi muka maupun belakang yang terbuka. Pada Gerbang masuk menggunakan bentuk bulatan dan lengkungan sebagai penghubung antar massa bangunan, motif klasik diterapkan pada lisplank yang dipasang pada sisi atap bangunan.

b. Langgam Transisi (1900-1920), langgam Arsitektur Transisi (Handinoto, 1996) kompromi bentuk arsitektur modern yang berkembang di Belanda pada masa tersebut, kemudian disesuaikan dengan iklim tropis di Indonesia. Bangunan menggunakan langgam ini menggunakan elemenelemen tradisional setempat yang diterapkan ke dalam bentuk arsitekturnya. PJH. Cuypers (18271921) merupakan seorang arsitek Neo-Gotik asal Belanda yang memulai langgam arsitektur ini.

c. Langgam Indo-Eropa (1920-1940), langgam Arsitektur Indo-Eropa berkembang sesudah tahun 1920-an, disebut juga dengan nama Niuwe Bouwen. Penggunaan langgam ini pada bangunan disesuaikan dengan iklim dan kemampuan teknologi setempat. Selain sebagai pelopor dari gaya internasional, langgam ini juga berkembang di wilayah Jerman, Belanda, dan Perancis.

Krier, 2001, menyatakan bahwa 'facies' merupakan kata latin dari fasad yang memiliki arti wajah dan penampilan [6]. Komposisi dari suatu fasad erat kaitannya dengan penciptaan harmonisasi antara setiap elemennya, diantaranya jendela, bukaan pintu, pelindung matahari, bidang atap yang bertujuan mencapai proporsi yang baik, termasuk diantaranya berdasarkan struktur vertikal dan horisontal, bahan, warna, serta elemen-elemen dekoratif lainnya.

Selain itu, Krier, (2001) menuliskan pula bahwa penjelasan dari elemen-elemen pendukung fasad bangunan diantaranya sebagai berikut [6]:

a. Pintu, memiliki peran penting serta sangat menentukan guna menghasilkan arah dan makna yang tepat dalam suatu ruang. Dimensi umum dari sebuah pintu yang biasa digunakan adalah menggunakan perbandingan proporsi 1:2 atau 1:3. Dimensi pintu biasanya memiliki makna yang berbeda, sebagai contoh pintu dengan ukuran pendek, digunakan sebagai pintu kedalam ruangan yang lebih privat.

b. Jendela, jendela akan memberikan pengalaman ruang orang yang berada di luar bangunan dapat membayangkan keindahan ruangan-ruangan dibaliknya dan begitu pula sebaliknya. Adapun beberapa hal yang harus diperhatikan ketika menyusunan jendela pada wajah bangunan, diantaranya:

- $\quad$ Proporsi geometris pada wajah bangunan

- Penataan komposisi, yaitu dengan pembuatan area wajah bangunan yang terencana

- harmonisasi proporsi geometri diperhatikan

- Wajah bangunan dipengaruhi oleh jendela yang diberikan, sehingga menjadi salah satu elemen utama fasad yang tidak dapat dihilangkan

- Jendela dalam kelompok-kelompok kecil, sebagai pembagi wajah bangunan dan akan membentuk symbol atau makna tertentu

c. Dinding menjadi salah satu unsur penting pembentukan wajah/raut bangunan. Penataan dinding juga dapat anggap sebagai bagian dari seni pahat sebuah bangunan, bagian tertentu dari bangunan yang dapat ditonjolkan dengan pengolahan dinding yang unik, yang bisa diperoleh dari pemilihan bahan, ataupun dengan cara finishing dinding, diantaranya tekstur, warna cat, dan juga teknik pengerjaannya. 
d. Atap merupakan bagian dari suatu bangunan, berfungsi sebagai penutup seluruh ruangan yang berada dibagian bawahnya. Selain itu atap adalah sebuah mahkota, yang berfungsi menambah estetika serta sebagai pelindung bangunan dari iklim panas dan hujan.

e. Sun Shading/Luifel yaitu fungsinya melindungi bagian wajah bangunan dari cuaca dan iklim. Penggunaan elemen arsitektural pada bangunan berfungsi sebagai pelindung wajah bangunan dari cuaca dan iklim. Sun shading merupakan elemen yang biasanya diletakkan di bagian atas wajah/fasad bangunan dan pada bukaan-bukaan bangunan.

Fasad bangunan menurut Prijotomo (1988), adalah wajah dari sebuah bangunan yang merupakan elemen arsitektur dan bagian bangunan dan yang paling mudah untuk dilihat. Pertimbangan persyaratan fungsional dalam komposisi suatu fasad bangunan. Kesatuan yang harmonis dengan penerapan komposisi yang proporsional, unsur horizontal dan vertikal yang terstruktur, material, warna dan elemen-elemen dekoratif merupakan prinsip keseimbangan komposisi dan fungsi pada elemen fasad bangunan. [7].

Aspek lain yang perlu dipertimbangkan dalam menciptakan point of interest pada fasad bangunan adalah proporsi bukaan, ketinggian dari bangunan, prinsip repetisi atau perulangan elemen fasad, keseimbangan komposisi yang baik, serta tema yang tercakup ke dalam variasi. Penerapan teritisan atau sun shading yang merupakan ornamen pada bidang dinding pada fasad bangunan merupakan bentuk adaptasi terhadap cuaca [8].

Ching (1995), menjelaskan, bahwa visual fasad bangunan dipengaruhi oleh wujud, warna, tekstur, serta dimensi. Komponen fasad bangunan, diantaranya adalah dinding batu, gerbang dan pintu masuk, koridor beratap. Elemen-elemen pembentuk fasad yang menunjukan citra suatu bangunan [9], antara lain:
a. Dinding
b. Kolom
c. Bukaan pada dinding
d. Entrance (pintu masuk)
e. Atap
f. Balkon
g. Warna dan finishing material
h. Papan tanda (sign)

\section{HASIL DAN PEMBAHASAN}

\subsection{Objek, lokasi dan Wilayah penelitian}

Lokasi objek penelitian berada di Kota Cirebon Kecamatan Lemah Wungkuk, jalan Kebumen no 49. Di daerah ini terdapat bangunan sekolah yang memiliki karakter dengan langgam Arsitektur Kolonial. Sebagian fisik bangunan telah mengalami perubahan tetapi keaslian langgam bangunan masih dipertahankan. Oleh karenanya pada peneliti ini di SMPN 16 Kota Cirebon dipilih sebagai objek studi. 

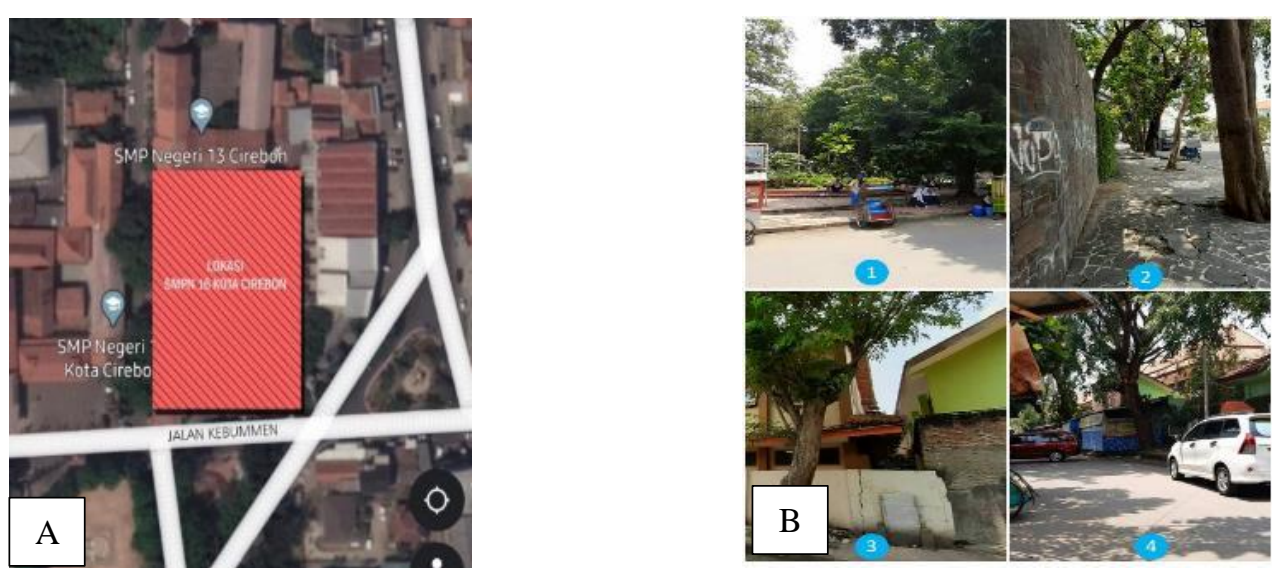

Gambar 3.1. (A) Lokasi sekolah SMPN 16 Kota Cirebon yang berada di Kec. Lemah Wungkuk, Kel. Lemah Wungkuk, Jalan Kebumen; (B) Batas site bangunan SMPN 16 Kota Cirebon Sumber : (A) Google Maps, 2020 ; (B) Data Bersama, 2020

1. Batas Utara : Taman Benteng Kebumen.

2. Batas Barat : Jalan Merdeka.
3. Batas Selatan : SMPN 13 Kota Cirebon

4. Batas Timur : Gang Karangmoncol

\subsection{Gambaran Umum SMPN 16 Kota Cirebon}

Sejarah menyatakan bahwa bangunan ini didirikan pada sekitar tahun 1933 dan menurut Surat Keputusan Walikota Cirebon No 9 tahun 2001 sudah ditetapkan sebagai bangunan cagar budaya. Menurut hasil wawancara dengan bapak Suripto atau sumber yang dapat dipercaya bangunan ini tadinya diperuntukan semacam asrama atau rumah sakit bagi tentara Belanda pada masa penjajahan. Namun, seiring bejalannya waktu sekitar tahun 1960-an hingga saat ini bangunan tersebut beralih fungsi menjadi bangunan pendidikan. Untuk menampung kegiatan pendidikan sekolah ini sudah menambah beberapa bangunan baru dan sudah beberapa kali mengalami renovasi, diantarnya ruangan kelas yang saat ini sudah terlihat modern. Perubahan tidak hanya secara fisik tetapi terjadi beberapa kali pergantian nama sekolah, yaitu:

1. Sekolah Kepandaian Putri (SKP) Negeri Cirebon

2. Sekolah Kesejahteraan Keluarga Pertama (SKKP) Negeri Cirebon.

3. Sekolah Lanjutan Tingkat Pertama (SLTP) Negeri 17 Cirebon.

4. Sekolah Mengah Pertama (SMP) Negeri 16 Cirebon.

5. Sekolah Menegah Pertama (SMP) Negeri 16 Kota Cirebon.

Semenjak adanya Undang-Undang Otonomi Daerah nama sekolah berubah menjadi "Kota Cirebon" karena pengertiannya Cirebon akan muncul pengertian baru apakah termasuk kotamadya Cirebon atau kabupaten Cirebon.

\section{Profil Sekolah}

\section{NIPSN}

Status

Bentuk Pendidikan

Status Kepemilikan

SK Pendirian Sekolah

Tanggal SK Pendirian

SK Izin Operasional

Tanggal SK Izin Operasional

\author{
: 20222183 \\ : Negeri \\ : SMP \\ : Pemerintah Daerah \\ : 0259/O/1994 \\ : 1994-10-05 \\ : 0259/O/1994 \\ : 1910-01-01
}


Penelitian ini di maksudkan untuk mengungkapkan karakteristik dari facade bangunan SMPN 16 Kota Cirebon. Adapaun dokumentasi dan data-data untuk makalah ini diambil pada tahun 2020.

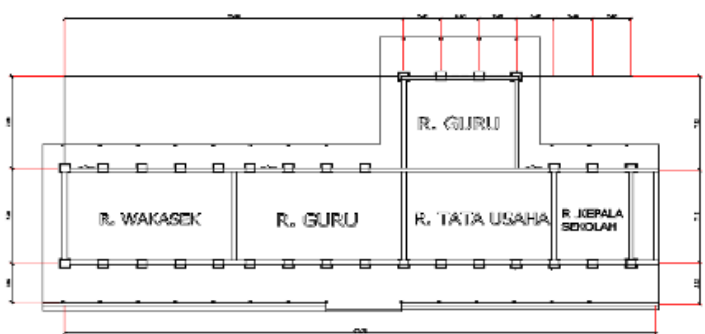

[A]
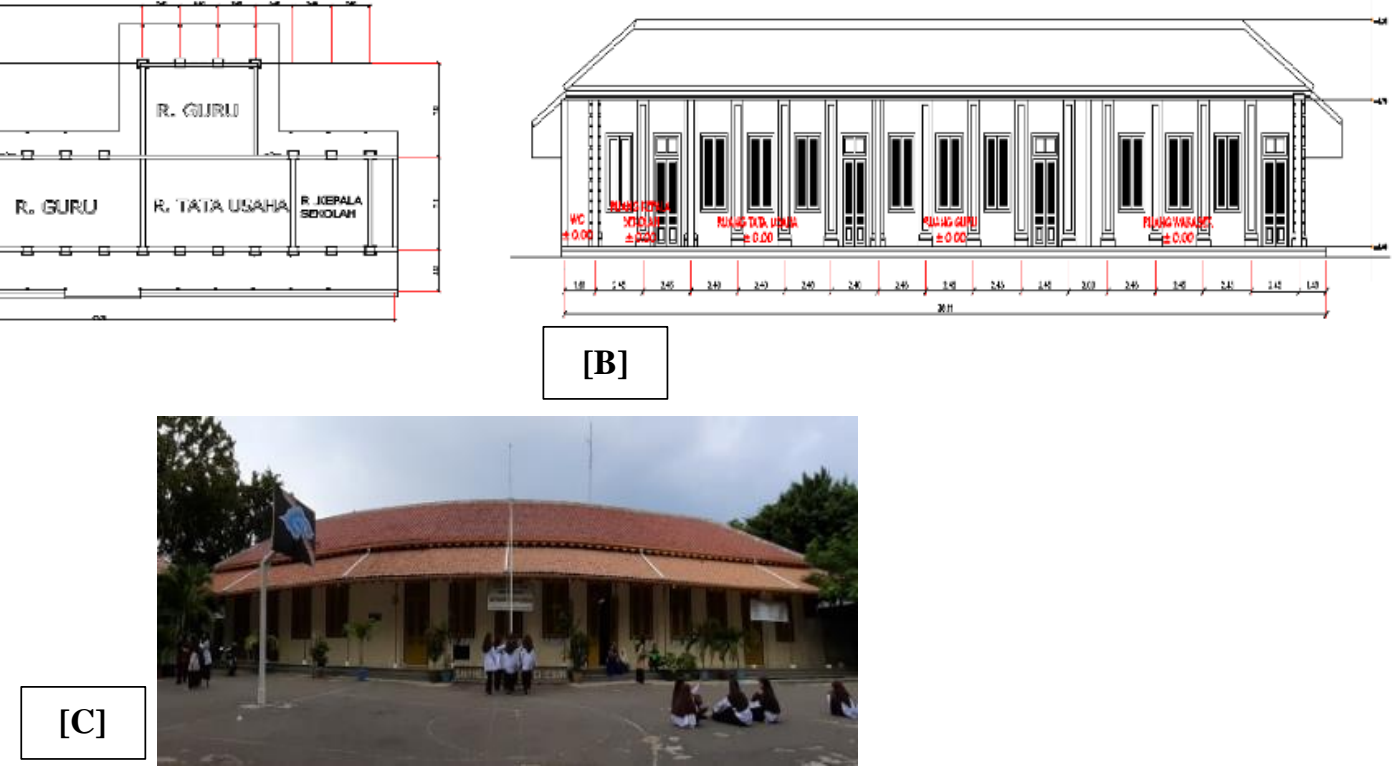

Gambar 3.2. [A].Denah; [B] Potongan dan; [C] Facade pada bangunan SMPN 16 Kota Cirebon Sumber : Hasil survey, 2020

Denah bangunan SMPN 16 Kota Cirebon ini memiliki fungsi ruangan masing-masing yaitu:

- Ruang Kepala Sekolah

- Ruang Wakil Kepala Sekolah

- 2 (dua) Ruang Guru

- Ruang Tata Usaha

Denah bangunan ini memiliki bentuk yang simetris yang mengacu pada gaya arsitektur "Indische Empire", memberikan gambaran bahwa secara umum arsitektur transisi memiliki karakter bangunan dengan bentuk denah serupa dengan arsitektur Indische Empire yang berkembang pada masa langgam arsitektur kolonial (periode tahun 1870-1900). Penerapan elemen arsitektural Indische Empire Style dengan karakteristik penggunaan pilar atau kolom besar dengan gaya yunani digantikan oleh kolom yang terbuat dari material kayu serta bentuk denah yang memiliki bentuk yang simetris antara sisi kiri dengan sisi kanan. Penggunaan tritisan di sekeliling bangunan bertujuan sebagai pelindung bangunan dari terpaan air hujan dan paparan sinar matahari pada bagian bidang bangunan secara langsung. Penggunaan material genting pada elemen penutup atap dan hiasan/ornamen pada atap atap perisai ditujukan untuk menimbulkan kesan mencolok.

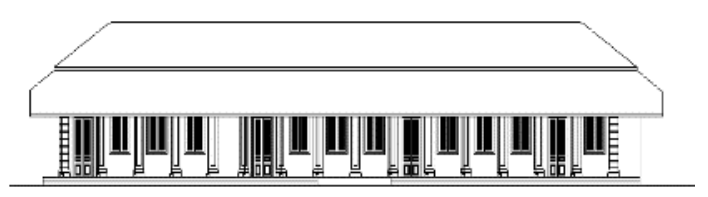

Tampak Depan

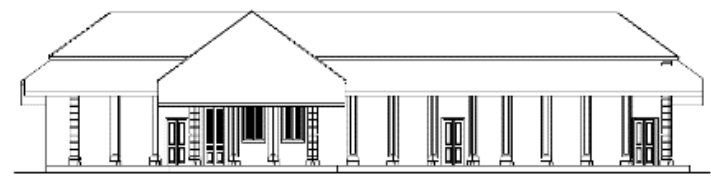

Tampak Belakang

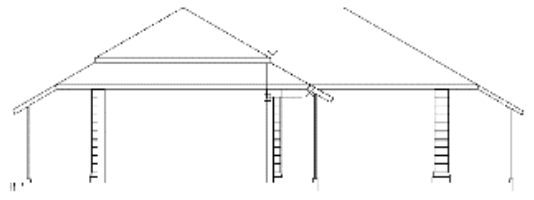

Tampak Samping Kanan

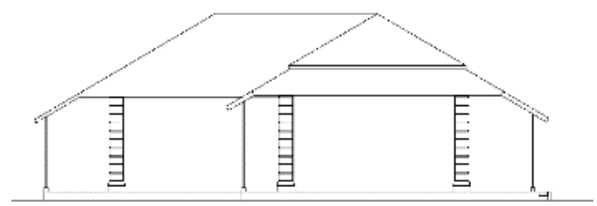

Tampak Samping Kiri

Gambar 3.3. Tampak SMPN 16 Kota Cirebon

Sumber : Hasil survey, 2020 


\subsection{Elemen Fasad}

\section{A. Atap}

Bentuk atap bangunan ini adalah atap perisai, termasuk dalam atap tradisional perpaduan budaya kolonial dengan buaya lokal. Penggunaan kemiringan yang tinggi pada atap perisai ini merupakan penyesuaian dengan iklim tropis daerah tersebut. Menurut Hellen Jessup, terdapat empat periode perkembangan Arsitektur Kolonial Belanda yang terdapat di Indonesia,[10]. Perkembangan Indische Architecture atau dikenal dengan nama Landhuise yang merupakan tipe bangunan di seluruh Hindia Belanda pada masa itu. Tipe ini memiliki karakter arsitektur sebagai berikut:
a. Terdapat pilar yang terletak di serambi tengah menuju ruang tidur serta kamar-kamar lainnya dengan bentuk denah simetris satu lantai dan terbuka.
b. Terdapat gevel atau mahkota yang terletak di atas serambi depan dan serambi belakang serta pilar menjulang keatas (Gaya Yunani).
c. Menggunakan atap perisai.
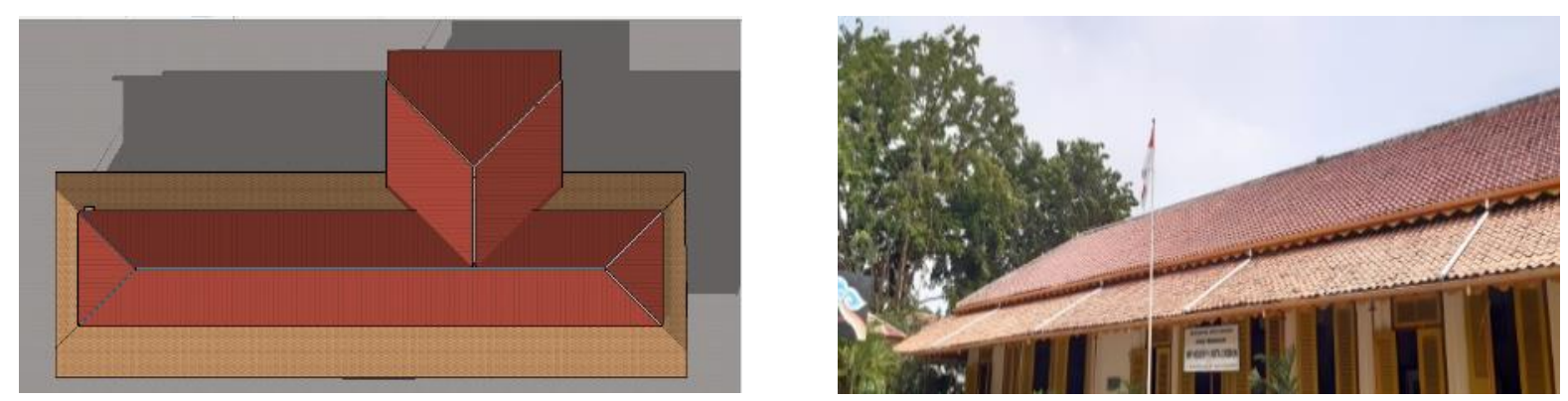

Gambar 3.4. Bentuk atap pada bangunan SMPN 16 Kota Cirebon Sumber : Hasil survey, 2020

Pada atap bangunan SMPN 16 Kota Cirebon memiliki dua umpak dan memliki kemiringan 30 -35 derajat. Atap asli sudah termakan usia sehingga diperlukan tindakan renovasi mengingat curah hujan yang cukup tinggi. Pekerjaan renovasi meliputi perbaikan wuwung dan genting, penambahan talang air dan juga konstruksi kuda-kudanya. Renovasi yang dilakukan tidak merubah gaya masih asli bangunan dan dengan atap tetap berbentuk perisai.

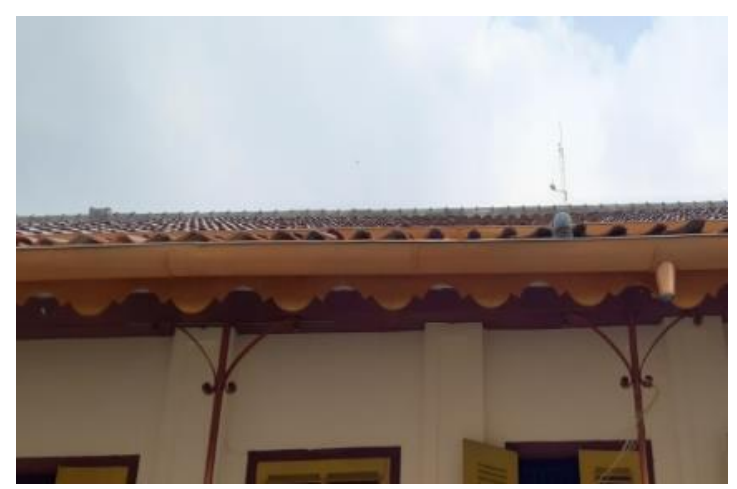

Gambar 3.5. Bentuk ornamen atap pada bangunan SMPN 16 Kota Cirebon Sumber : Hasil survey, 2020

Keunikan dari konstruksi atap adalah terdapat ornamen yang diletakkan pada listplank. Ornamen terbuat dari papan kayu dan merupakan permainan lengkung sederhana yang berirama dan simetris. Ornamen ini masih terjaga keasliannya dan pemeliharaan dilakukan dengan melakukan pengecatan secara berkala. 


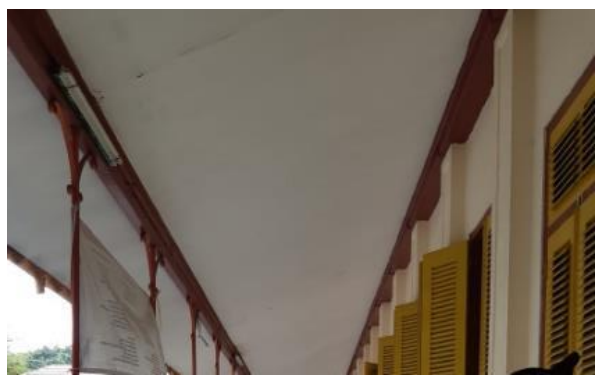

\section{Gambar 3.6. Bentuk Plafond pada bangunan SMPN 16 Kota Cirebon}

Sumber : Hasil survey, 2020

Plafond pada teras depan ini sudah diganti dengan gypsum yang di cat warna putih. Ketinggian dari plafond cukup tinggi hingga mencapai $4.76 \mathrm{~m}$ yang membuat bangunan ini terlihat luas dan besar.

\section{B. Kolom dan Dinding}

Hasil analisis menunjukkan bangunan ini menggunakan kontruksi dinding pemikul atau kolom tanpa beton. Kolom terbuat dari batu kali dengan campuran batu kapur dengan tebal kurang lebih $60 \mathrm{~cm}$.
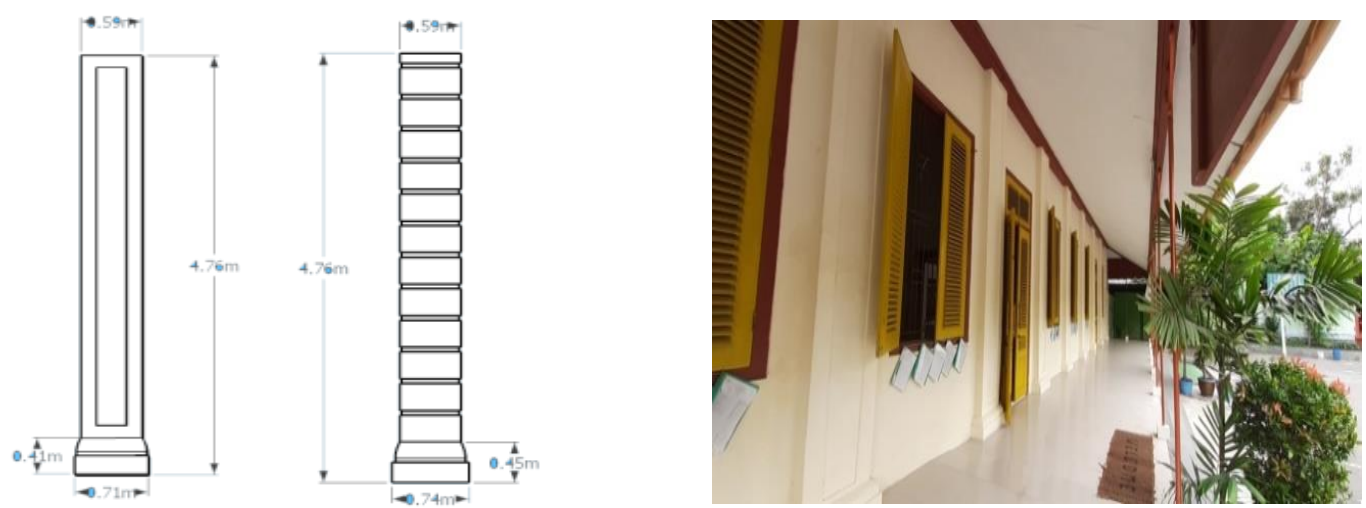

Gambar 3.6. Bentuk Kolom pada bangunan SMPN 16 Kota Cirebon

Sumber : Hasil survey, 2020

Hasil identifikasi menemukan tiga tipe kolom, dua diantaranya merupakan struktur penguat dinding, dibuat menonjol yang menjadi ornament dinding. Tipe lain adalah berfungsi sebagai penyangga pada tritisan teras. Dua tipe kolom yang terdapat pada dinding memiliki perbedaan pada ornamentnya sedangkan untuk warna semua menggunakan warna putih demikian pula dengan warna dindingnya. 

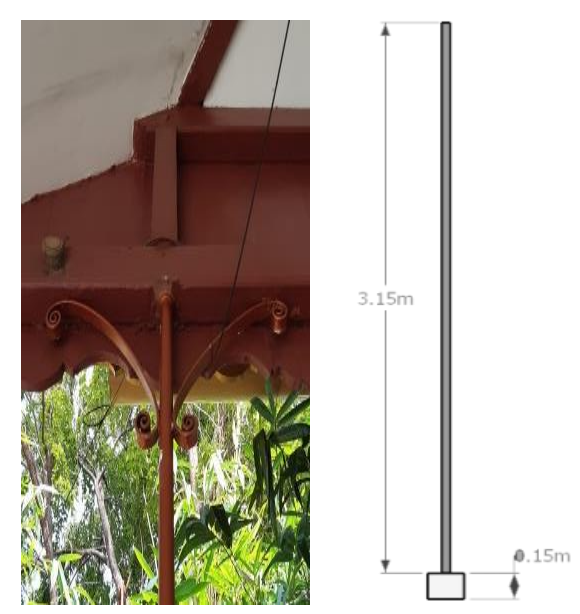

\section{Gambar 3.6. Bentuk Kolom pada teras bangunan SMPN 16 Kota Cirebon} Sumber : Hasil survey, 2020

Selain itu terdapat pula kolom/tiang yang terbuat dari besi dengan diameter $4 \mathrm{~cm}$. Dibagian ujung atas tiang terdapat ornament berbentuk bunga.

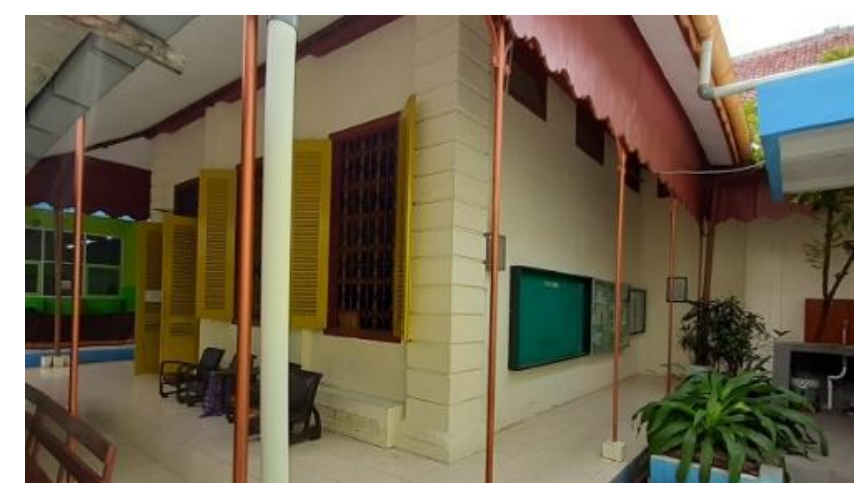

Gambar 3.6. Bentuk Dinding pada bangunan SMPN 16 Kota Cirebon Sumber : Hasil survey, 2020

Dinding merupakan penghalang atau partisi sebagai penyekat atau pembatas ruangan. Hasil analisis menunjukan dinding memiliki tinggi mencapai $4.76 \mathrm{~m}$ dan tebal $30 \mathrm{~cm}$ yang terbuat dari batu kali dengan campuran batu kapur. Permukaan dinding dibuat halus dan di cat dengan warna putih tetapi pada bagian luar masih mempertahankan warna aslinya.

\section{Pintu}

Pintu merupakan sebuah bukaan yang fungsi umumnya sebagai akses keluar masuk manusia, barang dan lain sebagainya. Ada 2 tipe pintu pada bangunan ini, umumnya memiliki lebar 1.4 meter dan terdiri dari 2 daun pintu terbuat dari kayu jati dengan mutu sangat baik.

Tipe pertama adalah pintu krepyak 2 daun yang dilengkapi dengan lubang angina di bagian atasnya dengan tinggi keseluruhannya mencapai 3.5 meter dengan lebar 1.2 meter.

Sedangkan tipe ke dua adalah pintu kayu 2 daun yang lebih rendah, yaitu 2.2 meter karena tidak dilengkapi dengan lubang angin tetapi mempunyai lebar 1.4 meter. 


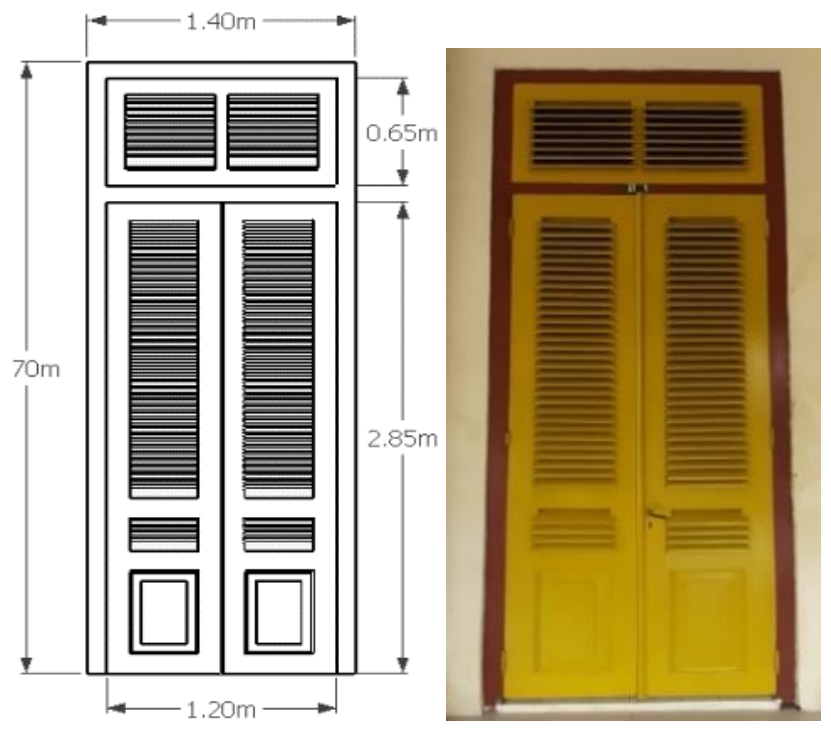

Gambar 3.6. Pintu tipe 1 pada bangunan SMPN 16 Kota Cirebon Sumber : Hasil survey,, 2020

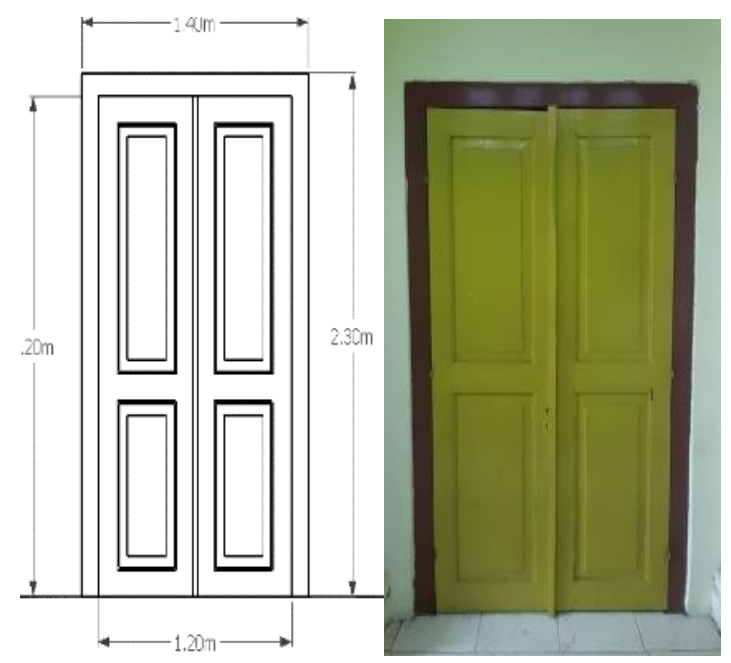

Gambar 3.6. Pintu tipe 2 pada bangunan SMPN 16 Kota Cirebon Sumber : Hasil survey, 2020

\section{Jendela}

Jendela dan lubang angin atau ventilasi berfungsi untuk mengalirkan udara masuk dari luar ke dalam atau sebaliknya. Ada 2 tipe jendela pada bangunan ini, yaitu jendela krepyak 2 daun terbuat dari kayu jati berkualitas tinggi. Ukuran jendela adalah lebar 1.4 meter dengan tinggi 2.4 meter. Pada beberapa bagian jendela sudah ditambahkan trails besi untuk keamanan.

Jendela tipeke 2 adalah lubang ventilasi dengan ukuran panjang 2,4 meter dan tinggi 0.60 meter terbuat juga dari kayu jati berkualitas tinggi. Daun jendela ditutup kaca dan dibuka dengan bantuan tali sehingga daun ventalasi dapat berputar namun sekarang sudah tak berfungsi lagi karena sudah termakan usia. 

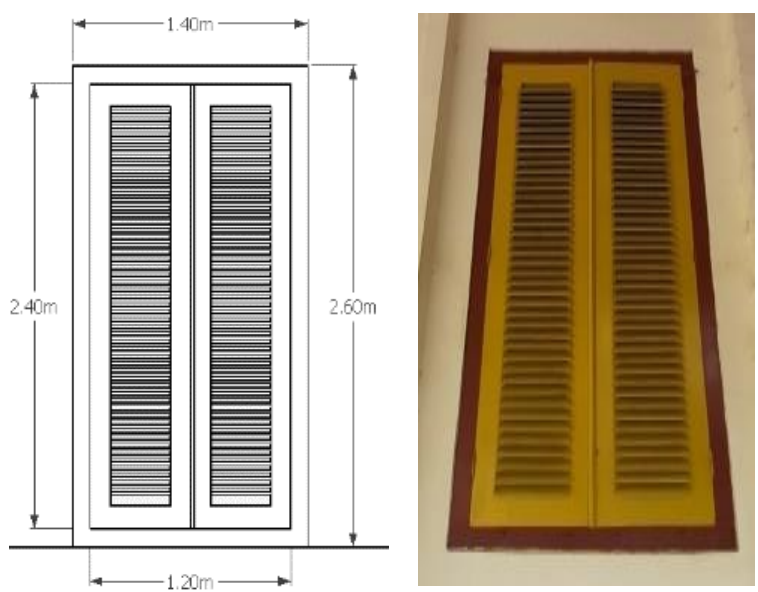

Gambar 3.6. Bentuk jendela pada bangunan SMPN 16 Kota Cirebon Sumber : Hasil surey, 2020
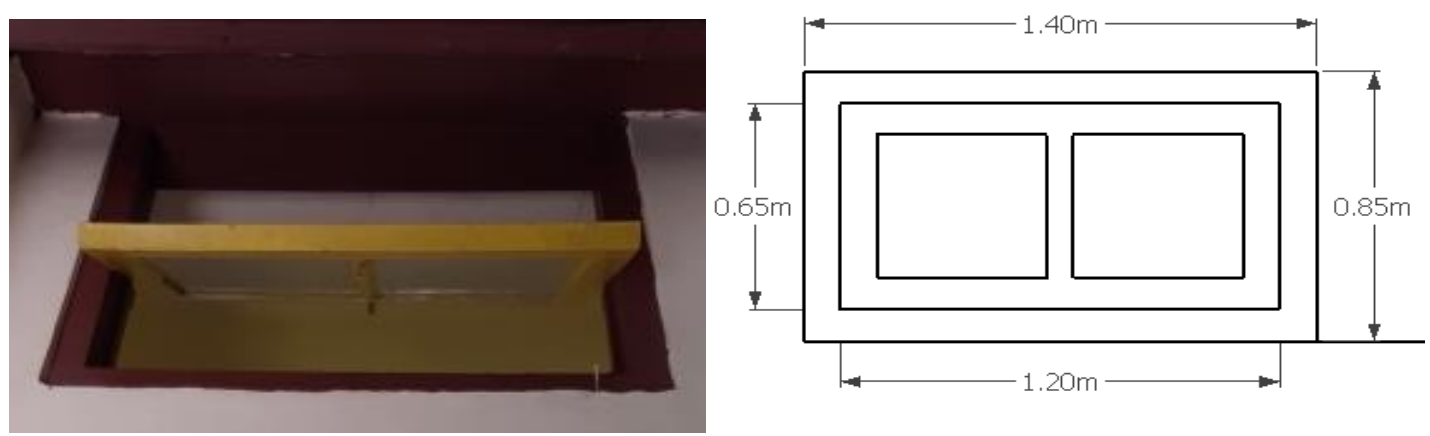

Gambar 3.6. Bentuk Ventilasi udara pada bangunan SMPN 16 Kota Cirebon Sumber Hasil survey, 2020

\section{E. Lantai}

Lantai merupakan sebuah pijakan atau alas sebuah bangunan. Pada elemen pola lantai ini sudah mengalami perubahan yang dahulunya masih menggunakan ubin tegel atau teraso bertekstur agak kasar yang dapat menyerap panas. Namun, sekarang sudah diganti semua dengan lantai keramik dengan ukuran 40 x $40 \mathrm{~cm}$ sedangkan teras bagian belakang memiliki ukuran 30 x $30 \mathrm{~cm}$ Tinggi ratarata lantai antara $20-36 \mathrm{~cm}$ dari permukaan halaman.
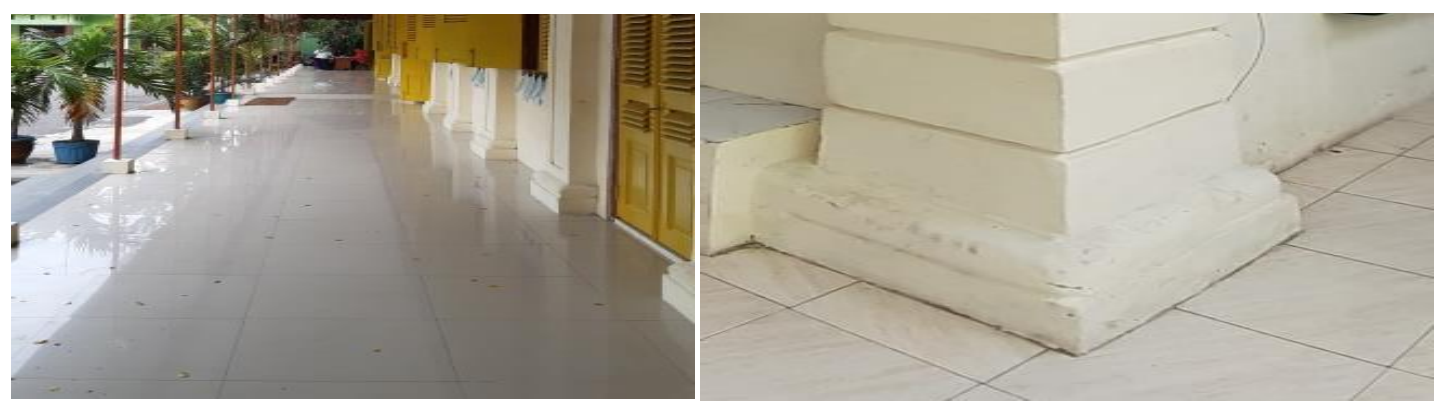

Gambar 3.7. Lantai keramaik pada bangunan SMPN 16 Kota Cirebon Sumber : Hasil survey, 2020 
Tabel 1. Rincian elemen-elemen pada Fasad

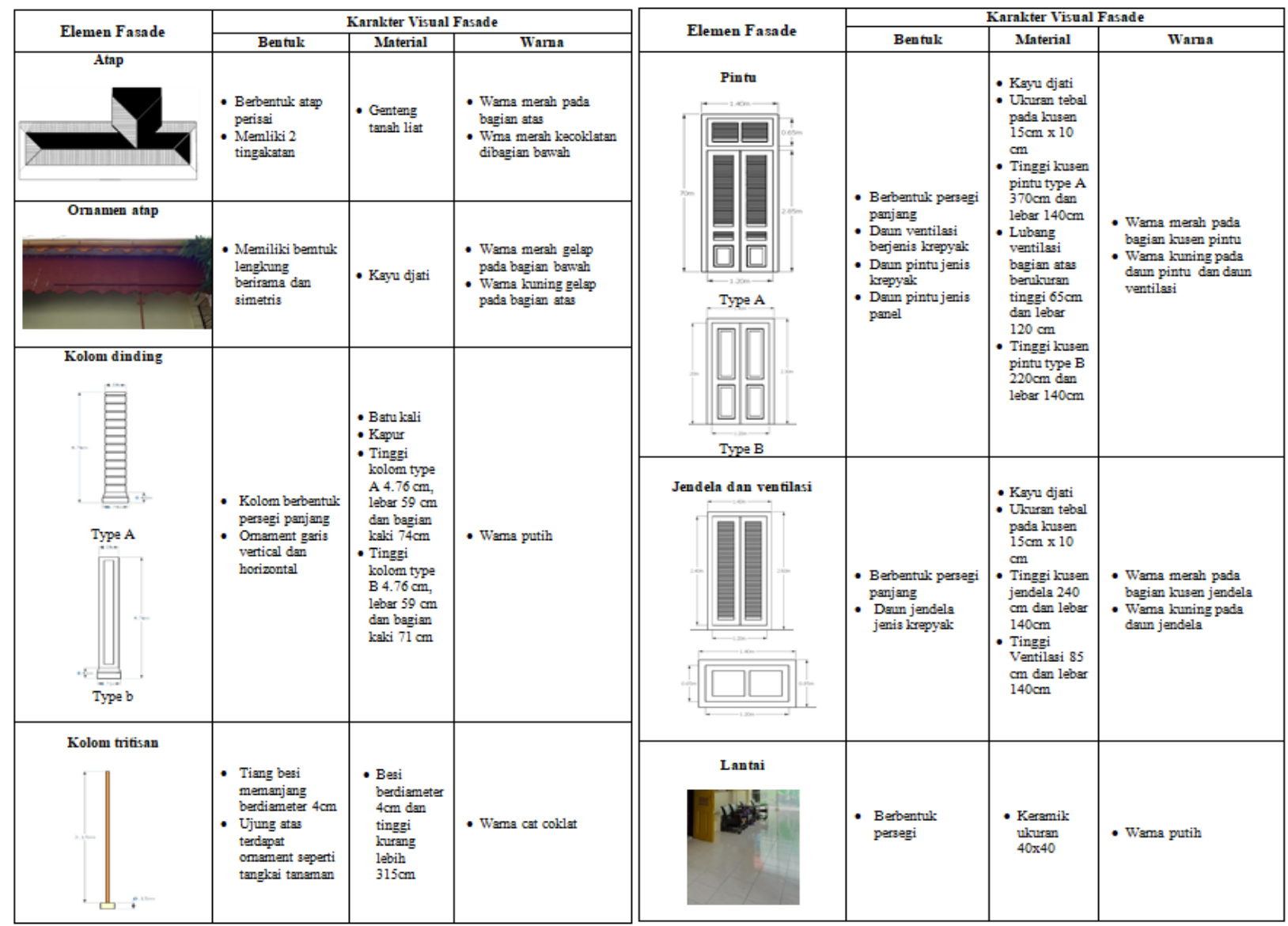

\section{SIMPULAN}

Dari hasil survey dan analisis dapat disimpulkan bahwa, bangunan SMPN 16 Kota Cirebon dipengaruhi oleh gaya arsitektur Indische Empire Style. Bangunan ini beradaptasi terhadap iklim tropis dan beradaptasi terhadap lingkungannya yang dapat diidentifikasikan dari penggunaan material local untuk bangunannya seperti kayu jati dengan mutu tinggi yang terdapat di sekitar kota Cirebon.

Denah berbentuk simetris yang mengacu pada gaya arsitektur "Indische Empire". Gaya arsitektur transisi atau peralihan yang mana bentuk denahnya serupa dengan langgam yang dimiliki Arsitektur Kolonial ( tahun 1870-1900) yaitu dikenal dengan langgam arsitektur Indische Empire.

Penutup genting tanah liat dengan bentukan atap perisai. Hiasan atau ornamen yang cukup mencolok diterapkan pada bagian atap. Atap dilengkapi dengan talang air, lisplank yang masih asli dengan konstruksi kuda-kudan kayu. Konstruksi kuda-kuda telah direnovasi dengan tetap mempertahankan bentuk aslinya.

Dinding bangunan masih terlihat kokoh dengan tambahan ornament kolom yang menjulang tinggi menciptakan kesan monumental pada bangunan. Kesan ini diperkuat dengan bentuk dan ukuran pintu jendela kayu krepyak yang berukuran tinggi yang menambah kesan megah. Pergantian bahan penutup lantai dengan keramik memberi nuansa modern pada bangunan ini.

Dari hasil pemantauan pada bangunan SMPN 16 Kota Cirebon dapat ditarik kesimpulannya bahwa bangunan ini mengalami perubahan yang tidak signifikan dan masih mempertahankan gaya lama dan nuansa bangunan kolonial. Sedangkan alih fungsi bangunan dari asrama tentara Belanda menjadi sekolah merupakan sejarah menarik yang harus dilestarikan dan menjadi salah satu kriteria penetapan 
bangunan cagar budaya. Bangunan cagar budaya sebagai warisan bangsa harus dijaga dan dan dilestarikan keberadaannya dan alih fungsi adalah salah satu metoda pelestarian.

\section{DAFTAR PUSTAKA}

[1] "SITUS CIREBON - Pemerintah Daerah Kota Cirebon." [Online]. Available: https://www.cirebonkota.go.id/pariwisata/kesenian-daerah/situs-cirebon/. [Accessed: 08-Jun2020]

[2] N. Muhadjir, Metodologi Penelitian Kualitatif Edisi IV. Yogyakarta: Penerbit Rake Sarasin. 2002.

[3] M. Safeyah, "Perkembangan 'Arsitektur Kolonial' Di Kawasan Potroagung.," Jurnal Rekayasa Perencanaan., vol. 3, no. 1, 2006. [Online serial]. Available: http://eprints.upnjatim.ac.id/1275/ [Accessed 08-Jun-2020]

[4] L.T. Tarore, Sangkertadi, I.R.B. Kaunang, "Karakteristik Tipologi Arsitektur Kolonial Belanda Pada Rumah Tinggal Di Kawasan Tikala", Jurnal Arsitektur Daseng Unsrat, vol. 5 no. 2, 2016. [Online serial]. Available: https://ejournal.unsrat.ac.id/index.php/daseng/article/view/14083/. [Accessed 08-Jun-2020]

[5] Hadinoto, Arsitektur dan Kota kota di Jawa pada Masa Kolonial, Graha Ilmu, Yogyakarta. 2020.

[6] R. Krier, Komposisi Arsitektur. Terjemahan Effendi Setiadharma. Jakarta: Erlangga. 2001.

[7] J. Prijotomo, Pasang Surut Arsitektur di Indonesia, Penerbit Arjun, Surabaya. 1988.

[8] R. Krier, Architectural Composition. London:Academy Edition. 1988.

[9] D.K. Ching, Visual Dictionary of Architecture. Willey,John \& Sons, Incorporated. 1995.

[10] Y. Sahmura, S. H. Wastuningrum, Identifikasi Langgam Dan Periodisasi Arsitektur Kolonial Nusantara Pada Bangunan Cagar Budaya, Jurnal Modul, vol. 18, no. 2, pp. 60-69, Nov. 2018. [Online serial]. Available: https://ejournal.undip.ac.id/index.php/modul/article/view/19016. [Accessed 08-Jun-2020] 